\title{
Lung Swap Method : \\ A Simple Method for Diagnosing the Drowning Cases
}

\author{
Djaja Surya Atmadja, Arif Budijanto, Yuli Budiningsih
}

\begin{abstract}
Abstrak
Telah dilakukan pemeriksaan mikroskopik cairan irisan paru, yang dinamakan pemeriksaan getah paru (lung swap method), terhadap 49 korban yang meninggal akibat tenggelam dan 25 korban yang meninggal bukan akibat tenggelam. Pada korban tenggelam didapatkan 91.8 \% (45 dari 49 kasus) kasus menunjukkan adanya plankton dalam cairan parunya, terdiri atas alga diatom dan alga non-diatom serta plankton non-alga. Pada 4 orang korban tenggelam tidak dijumpai adanya plankton sama sekali, dengan perincian 3 korban tenggelam dalam kolam dan 1 korban dalam bak mandi, yang diduga terjadi akibat airnya bersih dan bebas plankton. Pada kelompok korban bukan tenggelam, ditemukan 4 \% kasus (satu dari 25 kasus) dengan 3 jenis alga yang berbeda dalam cairan parunya, sedangkan 24 kasus lainnya tidak menunjukkan adanya plankton apapun. Pengujian kemaknaan dengan uji Fischer pada kedua kelompok menunjukkan adanya perbedaan yang bermakna $(p<0,001)$ dengan risk ratio 22,96 dan odd ratio 270,00. Komposisi plankton umumnya adalah campuran dengan dominasi diatom atau alga non-diatom dan hanya sedikit saja yang menunjukkan adanya plankton non-alga. Selain itu didapatkan bahwa pada kelompok tenggelain terdapat $14.4 \%$ ( 7 dari 49 kasus ) kasus dengan plankton non-diatom saja. Pada kasus ini pemeriksaan dengan metode destruksi asam, yang umum dikerjakan, akan memberikan hasil negatif palsu, karena plankton akan dihancurkan oleh asam. Pada kasus semacam ini pemeriksaan getah paru lebih unggul daripada pemeriksaan destruksi asam.
\end{abstract}

\begin{abstract}
The lung swap method is a method to search intact plankton microscopically in the lung fluid to diagnose the drowning death. In order to evaluate the efficacy of this method in differentiating the drowning from the non-drowning cases, as many as 49 cases of drowning and 25 cases of non-drowning death were examined. Among the drowning group, $91.8 \%$ ( 45 out of 49 cases) had planktons in the lung fluid, consisted of algae (diatom and non-diatom) and non-alga planktons. The other 4 cases had no plankton in their lung fluid, as 3 of them were drowned in the pool and the other one in a bathtub; both kinds of places contained relatively clean water which is suspected plankton-free. Among the non-drowning group, only $4 \%$ ( 1 out of 25 cases) was plankton positive, having 3 different species of non-diatom algae in the lung fluid, while the other cases showed no plankton at all. Statistically, using the Fischer test, the two groups showed a significant difference (p less than 0.001 , risk ratio 22.96 and odd's ratio 270.00). The composition of the planktons is usually mixed and showed either diatom or non-diatom alga domination. The non-alga plankton was rarely found in this study. Among the drowners, $14.4 \%$ (7 out of 49 cases) showed only non-diatom plankton in the lung fluid. In these cases the Acid Destruction method, which was the usual method for diagnosing drowning death using strong and concentrated acids, would give false negative results, because the acids would destroy the lung tissue and the non-diatom plankton. This means that in these cases, the lung swab method is superior than the acid destruction method.
\end{abstract}

Keywords : Drowning, Plankton, Lung swap method, Acid destruction method

\section{INTRODUCTION}

In the medicolegal practice, establishing the cause of death of the victims found in water is very essential. ${ }^{1,2}$ In such cases the most important question to answer is whether he or she was drowned or thrown into the water after death. ${ }^{3}$ Somebody is drowned if he falls into the water and died from the drowning process.

When somebody sink into the water, he usually tries to hold everything around him in order to survive. In that moment a few water begins to enter the 
respiratory and digestive tracts. A long and forceful effort to survive makes him fatique and he sinks deeper and deeper. At that time, more and more water flows into the bronchi and lungs. In some cases, laryngospasm and/or vagal reflex happen and the water is prevented to enter the lung; in such cases the cause of death is not drowning. 4,5

Together with the water, the foreign materials contained in the water (included plankton) also flow through the nostrils and mouth to the respiratory tracts and enter the lung's parenchym. ${ }^{2,4}$ The water fills the alveoli and prevents the gas exchange in the respiratory mechanism and causes asphyxia, terminal seizures and death. ${ }^{4}$ Planktons contained in the water also enter the alveoli, some of them penetrate the alveoli into the circulation and spread to the organs. Based on this phenomenon, there are some laboratory examinations introduced to diagnose the drowning death. ${ }^{5}$

The finding of diatom in the organs has been widely used as a diagnostic tool of the drowning death. ${ }^{1-8}$ This method is introduced for the first time in 1904, when accidentally Revenstof found diatoms in the fluid of the macerated lungs of the drowning victim. ${ }^{1,3,5}$ The method was improved with the addition of chemicals to destroy the tissue to make the microscopic field clearer. By adding strong acids, the lung tissue and the other material are destroyed. The only material left in the preparation was the diatom, a kind of alga which is acid-fast. ${ }^{1,5}$ The diatom has a silicate cell wall, which is a very strong material and resistant to various chemicals used in the destruction method. ${ }^{5,9}$ The method using strong acids is acid destruction method and still performed all over the world up to now. ${ }^{5}$ The other destruction methods using strong bases, digestive enzyme (such as pepsin) ${ }^{7}$ and ultrasound waves ${ }^{1}$ are then introduced to get better result. Apart from these methods there is another diatom searching method : the histopathologic examination of the lung tissue. ${ }^{1}$

The disadvantage of the destruction methods is the fact that it cannot detect the other plankton but diatom, because the non-diatom planktons are destroyed together with the lung tissue. ${ }^{5,7}$ In the drowning cases where the water only contains non-diatom planktons, the acid destruction method will give a false negative result. ${ }^{5,8}$

In the last few years, some authors have introduced some methods for detecting the presence of intact planktons without using the destruction methods. These methods tend to search all kinds of planktons (including diatom) rather than only diatom. By these methods the possibility of false negative results is prevented. Muraoka in 1974, cited by
Terazawa and Takatori ${ }^{6}$ has introduced the culture method of the lung fluid to diagnose the drowning death, especially if the plankton population is very few. Using this method, he has succeeded in harvesting the living colonies of diatom and green alga. Unfortunately the method is time consuming, because it takes about one week to get the result.

In 1980 Terazawa and Takator ${ }^{6}$ introduced a method to isolate intact plankton from the lung tissue homogenate by centrifugation in the coloidal silica gradient. Using this new method, they found diatom, green alga as well as zooplankton in the lung tissues of the drowning victims.

In Indonesia, especially in the Department of Forensic Medicine, Faculty of Medicine University of Indonesia, the acid destruction method has been performed for years. The acid used in this method are concentrated sulphuric and nitric acid. This method is performed in the fume chamber in order to protect the environment from polution by the acid fume. ${ }^{5,8}$ The overall proccess of this method take about 2 or 3 days to get the result. Unfortunately, in the other Forensic Centres and Primary Health Centres (Puskesmas) where the method need to be performed - usually there is no any fume chamber. In this condition, if they need to diagnose the drowning death, they must refer the lung tissue to the Forensic Centres with the proper facilities for acid destruction method. Based on this, the development of a simple and faster plankton detection method is essential (See figure 1-6).

This study is performed to introduce the lung swap method (uji getah paru), a method to detect intact planktons in the lung fluid microscopically. The objective of this study is to prove the effectiveness of the lung swap method in differentiating the drowning from the non-drowning death. The preliminary report of this study has been presented in the Ninth National Congress of Indonesian Pathology Association in Jakarta, $1987 .^{8}$

\section{MATERIALS AND METHODS}

The lung swap method was perfomed on 49 drowning cases and 25 non-drowning cases. To prevent the contamination of plankton from the water, the tap water in the autopsy room was examined microscopically for three consecutive days. The examinations showed that the tap water was plankton-free, thus it can be used to flush the lungs in this method. All of the objective and cover glasses were also examined microscopically before used. Only clean glasses were used for this examination. The knives and gloves for this examination were also the clean and dry ones. 


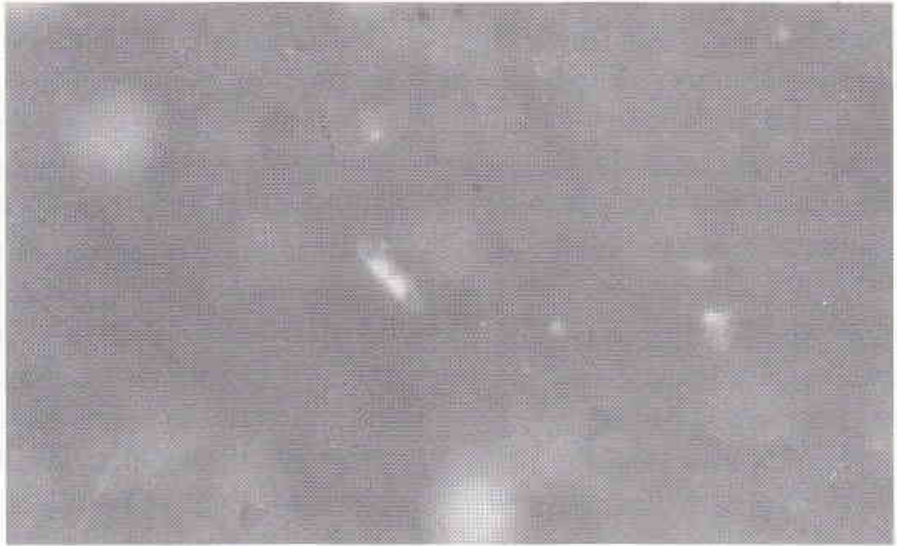

Figure 1. This is a species of diatom, with a compass-shaped and thick silicate wall. Inside the cell there are some undigested food. This is the most frequent diatom found in this study.

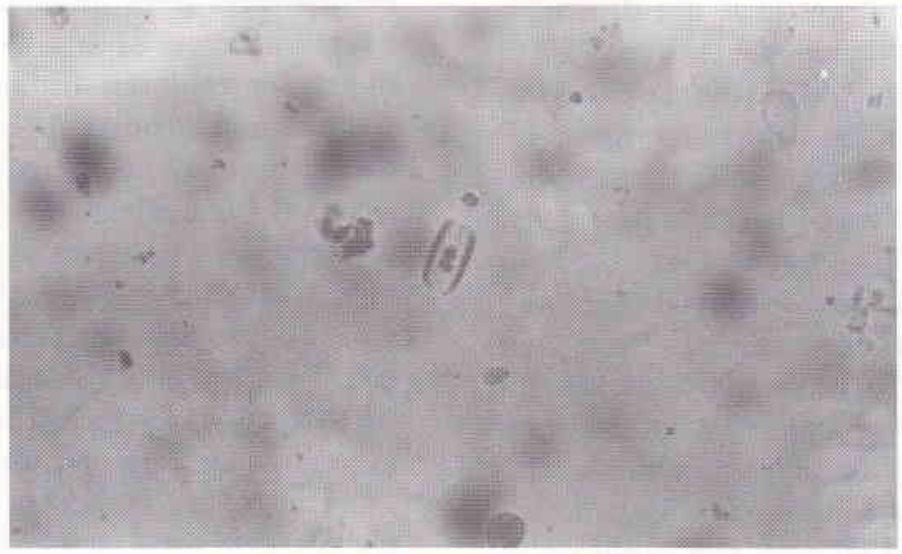

Figure 2. The other species of diatom with 2 "nucleus" and thick silicate wall.

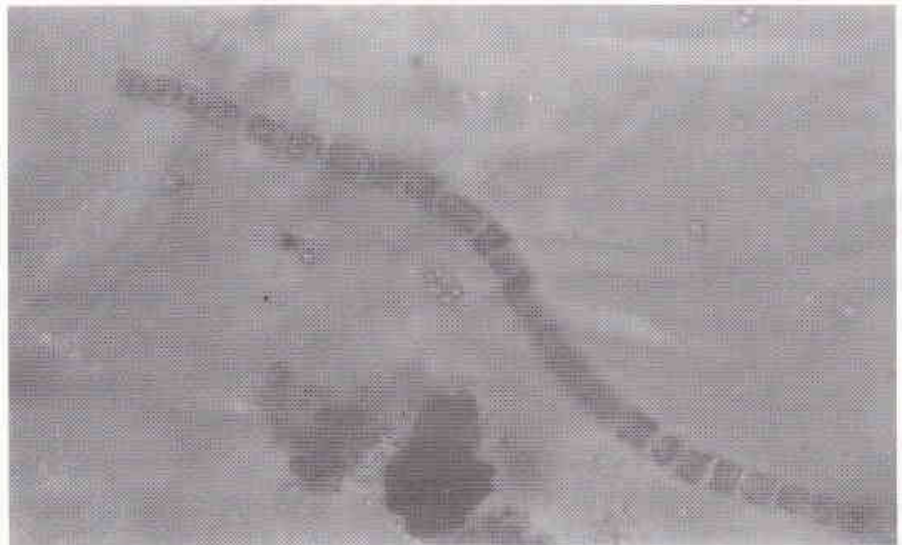

Figure 3. A fragment of thread-like alga, green in colour, with septa inside the structure. It is the most frequent alga found in this study. 


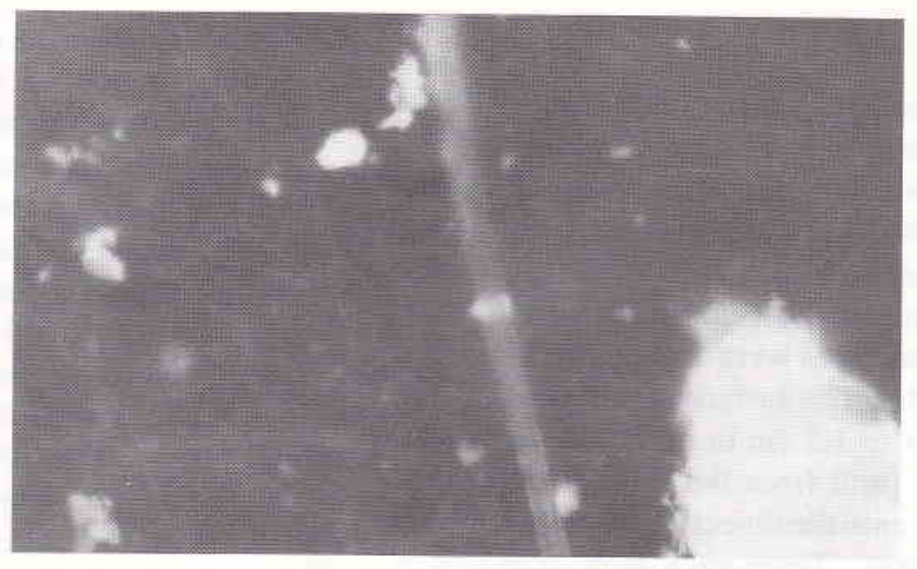

Figure 4. The other thread-like green alga, with the septa that are not so discrete as the alga in figure 3.

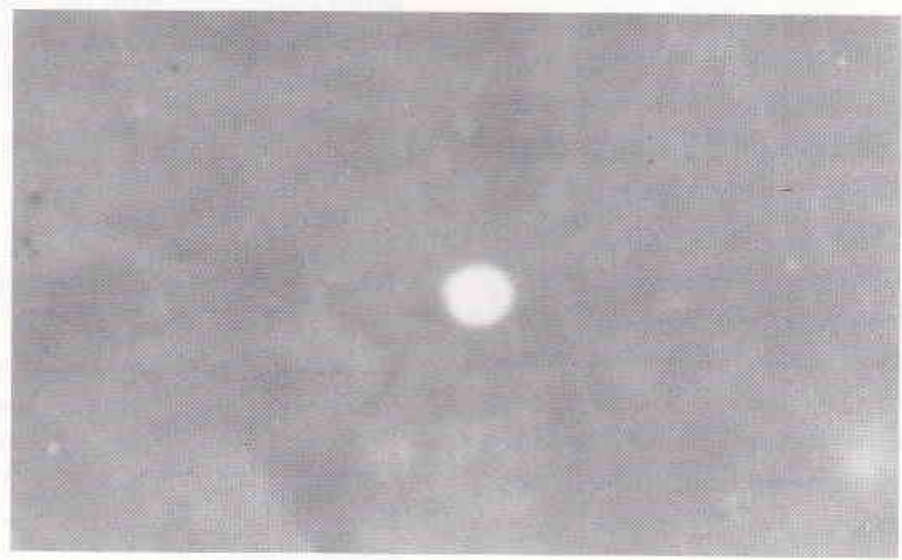

Figure 5. The example of unicellular green alga found in the lung fluid of a drowning victim.

Figure 6. Although not so frequent, sometimes we can find the cilliata like this as a member of non-alga planktons. This cilliata is the most frequent non-alga plankton in this study. 


\section{Collecting samples ${ }^{5,8}$}

After opening the chest cavities in the autopsy procedure, the doctor changed the gloves with the new ones. The left lung was removed from the pleural cavity after cutting the hyllus. The lung was prevented from touching the skin or others and flushed under the flowing tap water to make it clean. As soon as the water becomes clear, the lung surfaces were swept by the back of a knife to make it dry. The surface was incised about $3 \mathrm{~cm}$ in length and 1 to $1.5 \mathrm{~cm}$ in depth. Using the back of the knife, the fluid from the wall of the incision was collected, put onto the objective glass and covered with the cover glass. From each lung, two incisions were made, thus there were 4 microscopic preparations from both lungs of a case.

Microscopic examination was executed systematically on the whole field using the light microscope. To get the better contrast, the diameter of the diafragm was decreased and the condensor was a little bit lowered. The plankton was searched using the magnification of $100 \mathrm{X}$ and $400 \mathrm{X}$, photographed and the number of every plankton was counted and noted. Species identification was performed by comparing the plankton in the preparations to the plankton from the references. ${ }^{10-13}$ The lung swap is positive if there is at least one plankton in the preparations and negative if there is no plankton in the preparation. Every examination is done by at least 2 doctors for check and recheck.

Statistic analysis was performed using the Chi square or Fischer test to determine the significant different between the groups.

\section{RESULTS}

During this study, we found that some objective glasses had been contaminated by thread-like-alga (Nostoc sp and Vaucheria sp).

Totally, the lung swap method was performed on 49 drowning cases and 25 non-drowning cases. The non-drowning cases consisted of 22 traffic accident cases, 2 hanging cases and 1 gunshot wound case. They consisted of 17 males and 8 females, and the mean of the ages was $34.96 \pm 18.77$ years old (ranging from 4 to 70 years old).

The drowning cases consisted of 44 males and 5 females, and the mean of the ages was $24.51 \pm 9.17$ years old (ranging from 0 to 47 years old). Forty six cases were pure drowning cases, while the three others were murder cases with drowning as the contributary factor to death. The location of the drowning were the river ( 29 cases), pool (10 cases), sea ( 5 cases), lake ( 2 cases), water drainage ( 2 cases) and bath tub (1 cases)(Table 3).
Among the drowning cases, $91.8 \%$ (45 cases out of 49) showed planktons in the lung fluid (the Lung Swaps were positive)(Table 3). Among the remaining four cases where Lung Swaps were negative, three of them were found in the pool and the other one in the bath-tub. On the other hand, among the non-drowning cases only one out of 25 cases (4\%) of the cases where the Lung Swap was positive. The statistical analysis showed that the groups were significantly different with $\mathrm{X}^{2}=50.63, \mathrm{p}$ less than 0.001 , Relative risk $=$ 22.96 and Odd's ratio $=270.00$ (Table 1 ).

Analysis of the composition of the plankton showed that most of the cases showed combination of the various kinds of diatoms, non-diatom algae and non-alga planktons. About half of the cases showed either diatom or non-diatom alga domination. Among the drowning cases 7 out of 49 cases (14.4\%) showed only non-diatom planktons in the lung fluid. The nonalga plankton was found on 11 cases, together with other planktons with the variation from one to 3 kinds per case. The kinds of non-alga plankton found in this series were 15 Cilliata and 2 Euglena sp (Table 2).

Table 1. Lung swap results of the drowning and non-drowning cases, Jakarta, 1992

\begin{tabular}{lccc}
\hline Cases & \multicolumn{2}{c}{ Lung swap results } & Total \\
& Positive & Negative & \\
\hline Drowning & 45 & 4 & 49 \\
Non-drowning & 1 & 24 & 25 \\
\hline Total & 46 & 28 & 74 \\
\hline
\end{tabular}

Table 2. Distribution of the drowning cases according to the plankton composition, Jakarta, 1992.

\begin{tabular}{lrr}
\hline $\begin{array}{l}\text { Plankton } \\
\text { composition }\end{array}$ & $\begin{array}{c}\text { Number of cases according to the } \\
\text { kinds of species }\end{array}$ & quantity of plankton \\
\hline Diatom dominant & 11 cases & 13 cases \\
Diatom = non-diatom & 9 cases & 5 cases \\
Non-diatom dominant & 12 cases & 13 cases \\
Only diatom & 6 cases & 5 cases \\
Only non-diatom & 7 cases & 9 cases \\
No plankton & 4 cases & 4 cases \\
\hline Total & 49 cases & 49 cases \\
\hline
\end{tabular}


Table 3. The results of lung swap examination on the drowning cases, Jakarta, 1992.

\begin{tabular}{|c|c|c|c|c|c|c|c|}
\hline No. & Location & $\begin{array}{c}\text { Species } \\
\text { D }\end{array}$ & $\begin{array}{c}\text { Species } \\
\text { nD }\end{array}$ & $\begin{array}{c}\text { Species } \\
\mathrm{nA}\end{array}$ & $\begin{array}{c}\text { Number } \\
\text { D }\end{array}$ & $\begin{array}{c}\text { Number } \\
\text { nD }\end{array}$ & $\begin{array}{c}\text { Number } \\
\text { nA }\end{array}$ \\
\hline 1 & River & 2 & 4 & 0 & 2 & 4 & 0 \\
\hline 2 & Pool & 1 & 1 & 0 & 1 & 1 & 0 \\
\hline 3 & Pool & 2 & 3 & 0 & 2 & 5 & 0 \\
\hline 4 & River & 1 & 1 & 0 & 35 & 2 & 0 \\
\hline 5 & Bath tub * & 0 & 0 & 0 & 0 & 0 & 0 \\
\hline 6 & Pool & 1 & 0 & 0 & 1 & 0 & 0 \\
\hline 7 & River & 1 & 13 & 0 & 3 & 17 & 0 \\
\hline 8 & River & 1 & 9 & 0 & 1 & 94 & 0 \\
\hline 9 & Lake & 2 & 2 & 1 & 3 & 3 & 1 \\
\hline 10 & River & 0 & 1 & 0 & 0 & 3 & 0 \\
\hline 11 & River & 6 & 0 & 1 & 13 & 0 & 1 \\
\hline 12 & Pool & 0 & 1 & 0 & 0 & 2 & 0 \\
\hline 13 & River & 3 & 3 & 0 & 6 & 3 & 0 \\
\hline 14 & River & 1 & 0 & 0 & 101 & 0 & 0 \\
\hline 15 & River & 5 & 1 & 0 & 11 & 1 & 0 \\
\hline 16 & River & 1 & 2 & 0 & 2 & 2 & 0 \\
\hline 17 & Drainage & 0 & 6 & 1 & 0 & 6 & 1 \\
\hline 18 & River & 3 & 0 & 1 & 5 & 0 & 1 \\
\hline 19 & River & 2 & 2 & 0 & 2 & 2 & 0 \\
\hline 20 & Drainage & 5 & 3 & 1 & 5 & 3 & 2 \\
\hline 21 & Pool & 0 & 1 & 0 & 0 & 1 & 0 \\
\hline 22 & River & 2 & 2 & 2 & 2 & 6 & 2 \\
\hline 23 & River & 4 & 5 & 0 & 4 & 5 & 0 \\
\hline 24 & River & 2 & 2 & 0 & 2 & 3 & 0 \\
\hline 25 & River & 12 & 11 & 2 & 24 & 13 & 2 \\
\hline 26 & Pool * & 0 & 0 & 0 & 0 & 0 & 0 \\
\hline 27 & River & 0 & 1 & 0 & 0 & 2 & 0 \\
\hline 28 & Sea & 2 & 1 & 0 & 2 & 8 & 0 \\
\hline 29 & Sea & 4 & 2 & 0 & 5 & 2 & 0 \\
\hline 30 & Sea & 4 & 3 & 0 & 9 & 3 & 0 \\
\hline 31 & River & 10 & 5 & 3 & 11 & 5 & 4 \\
\hline 32 & River & 7 & 3 & 1 & 7 & 3 & 1 \\
\hline 33 & Pool & 1 & 0 & 0 & 1 & 0 & 0 \\
\hline 34 & River & 1 & 1 & 0 & 1 & 1 & 0 \\
\hline 35 & Pool & 0 & 7 & 1 & 0 & 84 & 1 \\
\hline 36 & River & 1 & 3 & 2 & 1 & 3 & 2 \\
\hline 37 & River & 2 & 3 & 0 & 2 & 4 & 0 \\
\hline 38 & River & 4 & 5 & 0 & 13 & 77 & 0 \\
\hline 39 & River & 0 & 1 & 0 & 0 & 1 & 0 \\
\hline 40 & River & 5 & 7 & 0 & 7 & 10 & 0 \\
\hline 41 & Pool * & 0 & 0 & 0 & 0 & 0 & 0 \\
\hline 42 & River & 0 & 1 & 0 & 0 & 2 & 0 \\
\hline 43 & Sea & 4 & 2 & 0 & 4 & 2 & 0 \\
\hline 44 & Sea & 4 & 3 & 0 & 9 & 3 & 0 \\
\hline 45 & River & 9 & 9 & 0 & 18 & 9 & 0 \\
\hline 46 & River & 10 & 2 & 0 & 10 & 2 & 0 \\
\hline 47 & Lake & 2 & 1 & 0 & 2 & 1 & 0 \\
\hline 48 & River & 0 & 7 & 0 & 0 & 85 & 0 \\
\hline 49 & Pool * & 0 & 0 & 0 & 0 & 0 & 0 \\
\hline
\end{tabular}

Notes : * : cases with the negative results.

$\mathrm{D}=$ diatom; $\mathrm{nD}=$ non-diatom; $\mathrm{nA}=$ non-alga 


\section{DISCUSSION}

When a body is found in the water or lying in the bank of a lake, river, seashore or water drainage, the doctor should determine whether the victim sank into the water while he or she was alive (drowned) or after death. Drowning is a cause of death in which defective oxygenation of the blood occurs in the lungs due to the presence of fluid that enters the air passage through the nostrils and mouth. ${ }^{5,14}$

The diagnosis of drowning was based on the autopsy and laboratory findings. The main findings in the external and internal examinations are the immersion signs and asphyxial signs. The skin is cold, clammy, wet and sometimes soiled by mud, sand or weed. The skin of the hands and feet are sodden and wrinkled ("washer woman hand"), while the other parts of skin is rough ("cutis anserina" or "goose skin") due to the contraction of erector pili muscle. ${ }^{5,14}$

Asphyxia causes the congestion of the viscera, postmortem fluidity of the blood, cyanosis, cardiac dilatation and petechial haemorrhage in the serous membranes. In and on the mouth and nostrils there is a bulge of fine lathery tenacious froth in the shape of a small balloon or mushroom, white or pinkish in colour. This froth is also found in the lumen of the respiratory tracts. The lungs are large, distended, cyanotic, congested, oedematous, stiff and heavy and sometimes show some rib marking on the surfaces. Paltauf's haemorrhages, the haemorrhage due to the tearing of the interalveolar partition by the flow of water into the alveoli, are also found in the lung surfaces in some cases. The stomach and intestines may be full of water, sometimes contain mud, sand, weeds or plankton. ${ }^{5}$

The laboratory examinations are usually performed to establish the diagnosis of drowning. Some chemical tests have been developed for diagnosing the drowning. The most popular method is the determination of the chloride, sodium, potassium and magnesium concentration in the blood from ventricles of the heart. ${ }^{15-16}$ The other methods, such as the changes of peroxidase, aldolase and cytochrome oxydase in the lung homogenates, ${ }^{17}$ the changes of magnesium concentration in the cerebrospinal fluid, ${ }^{18}$ etc. have been introduced, but they still need further investigation to be used as diagnostic method in drowning cases. Unfortunately, the efficacy of these methods, especially depends on the postmortem period. These methods are reliable only within 24 hours postmortem period, when the bodies are still fresh. Since the drowning victims are usually found after considerable period of time, when the decomposition has been advanced, these chemical methods cannot be applied on most of the cases. ${ }^{5,8,9}$ In such situations, the search of the planktons in the lungs and other organs is the only valuable test for diagnosing the drowning. 5,8

The planktons (including diatoms), can be detected in the lungs fluid of the drowning victims, even if the decomposition is very advanced. ${ }^{5}$ As one of the components of the water, the planktons (including diatoms) enter the alveoli together with the water through the mouth, nostrils and the respiratory tracts during the drowning proccess. Some of the diatoms, especially the small ones, penetrate the blood vessels and are distributed to the organs. ${ }^{1,5,8,9}$ The finding of plankton(s) in the lung tissue or other organs establish the diagnosis of drowning. On the contrary, the negative finding does not mean that the case is not drowning, because the finding of the planktons depends on their presence in the water. In the clean water or very contaminated water there is possibility that there is no plankton in the water and the examination of the victims drowned in such water will result on negative finding. ${ }^{5,8}$

Since the plankton can be found almost everywhere, the specimen in the plankton search can be contaminated by plankton from the dust, food ${ }^{2,5,7}$ skin of the victims, glasswares or chemicals used. ${ }^{1,2,3,5}$ In order to get the most reliable result, prevention of contamination is an essential procedure in this method. In this study, the tap water for flushing the lungs was examined microscopically before used. Since there was no plankton in the tap water of the autopsy room, the water can be used. If the tap water shows any plankton, it is advisable not to use it. Other prevention of contamination procedures are suggested, such as preventing the lungs from touching the skin or others, using the new, clean and dry gloves and knife as well as examining the glassware before used. ${ }^{5,8}$ In this study we found that some glasswares have been contaminated by thread-like alga. All of these contaminated glasses were not used in this study. These findings should aware us that the examination of the glassware before using it for the lung swab method is essential to get a reliable result.

Among the drowning cases, $91.8 \%$ showed some planktons in the lung fluid, while the other 4 cases were plankton-free. 'These four cases were drowned in the pool with regular water exchange (three cases) and bath tub (one case), containing relative clean water. In such water there is a possibility that there is no plankton, but unfortunately, we do not have the chance to prove it. In the case of the drowning in the pool, the administration of sodium hypochloride to the water may be an additional factor that prevent the reproduction of the plankton. 
On the contrary to the drowning cases, only $4 \%$ (one out of 25 cases) of the non-drowning cases showed planktons in the lung fluid. In this only case, there were 3 different species of algae in the lung fluid. This case is a traffic accident, without any information whether the victim was thrown into the water drainage or not during the accident. Thus, we don't know where the planktons are derived from.

Among the 49 drowning cases, 7 cases (14.4\%) showed only non-diatom plankton in the lung fluid. Although the lung swap test in these 7 cases were positive, it can be predicted that it will have false negative results on acid destruction method, because all of these non-diatom planktons will be destroyed together with the lung tissue. In this kind of drowning (the percentage is big enough : $14.4 \%$ ), the lung swap method is more superior than the acid destruction method.

\section{CONCLUSION}

The lung swap method is a method of microscopic search for the intact plankton in the lung fluid to establish the diagnosis of drowning. This method is faster and simpler than the acid destruction method, the common method for diagnosing the drowning cases. The presence of any kinds of plankton will prove the drowning, while a negative finding do not mean that drowning has not happened. If the drowning has happened in the plankton-free water, the result will be false negative.

This study showed that the lung swap method is an effective method to establish the diagnosis of the drowning cases. In this method the prevention of contamination procedures are very essential to get a reliable result. On the cases in which the water only contains the non-diatom planktons (14.4\%), the lung swap method results in positive findings, while by acid destruction method the result will be false negative due to destruction of the non-diatom plankton by the acids. In these cases the lung swap method is more superior than the acid destruction method.

\section{Acknowledgement}

This study was partially supported by the research grant from DIP UI 1991/1992. The authors would like to express their gratitute to Dr. Wibisana Widiatmaka, Head of the Department of Forensic Medicine, Facul- ty of Medicine University of Indonesia for his supports and advices in writing this report.

\section{REFERENCES}

1. Fukui Y, Hata M, Takahashi, Matsubara K. A new method for detecting diatom in human organs. Forensic Sci Inter 1980; 16:74-87.

2. Peabody AJ. Diatoms and drowning, a review. Med Sci Law 1980;4:254-61.

3. Gee DJ. Lecture notes in Forensic Medicine. Second ed. Oxford: Blackwell Scientific Publ 1975:144-8.

4. Foget $N$. Diatom and drowning, one more. Forensic Sci Inter 1983;21:153-9.

5. Atmadja DS. Drowning and its significance of the diatom test. In: Sawaguchi T, ed. Causality and non-causality. First ed. Tokyo: Forensic Press Tokyo and Kanazawa, 1992;1334.

6. Terazawa $\mathrm{K}$, Takatori T. Isolation of intact plankton from drowning lung tissue by centrifugation in colloidal silica gradient. Forensic Sci Inter 1980;16:63-6.

7. Timperman I, Thomas F. Diatom identification and the diagnosis of drowning. In: Perper JA, Wechts $\mathrm{CH}$, eds. Microscopic diagnosis in Forensic Pathology. Springfield: Charles C Thomas 1980:211-25.

8. Atmadja DS, Budiningsih Y, Budijanto A. Pemeriksaan getah paru pada kasus-kasus mati tenggelam dan bukan tenggelam (laporan pendahuluan). Kongres Nasional Ikatan Allli Patologi Indonesia ke IX, 1987; Jakarta.

9. Hendey NI. The diagnostic value of diatoms in cases of drowning. Med Sci Law 1973;13(1):23-34.

10. Weisz PB. The Science of Biology. First ed. New York:Mc Graw Hill 1963:178-93.

11. Pelczar MJ, Chan ECS. Dasar-dasar Mikrobiologi I. Jakarta: UI Press 1986:237-55

12. Vashishta BR. Botani for Degree Students, part I. Algae. Ram Nagar-New Delli: S Chand and Co, 1984.

13. Wheathermax P. Plant Biology. Second ed. London: WB Saunders 1947:262-77

14. Atmadja DS. Kematian akibat tenggelam. Maj Kedok Indon 1991;41(3): 160-4.

15. Schwart TG. Drowning, its chemical diagnosis, a review. Forensic Sci 1972;1:411-7.

16. Modell JH. Biology of drowning. Ann Rev Med 1978;29: $1-8$.

17. Spitz WN, Silverman RA, Michael. Biochemical changes in Experimental drowning, pulmonary oedema and asphyxia. J Forensic Med 1969;16:79-85.

18. Coutselinis A, Boukis D. The estimation of $\mathrm{Mg}^{2+}$ concentration in the cerebrospinal fluid ( CSF) as a method of drowning diagnosis in sea water. Forensic Sci 1976;7:109-11. 